medRxiv preprint doi: https://doi.org/10.1101/2021.09.27.21263712; this version posted September 29, 2021. The copyright holder for this preprint (which was not certified by peer review) is the author/funder, who has granted medRxiv a license to display the preprint in perpetuity.

It is made available under a CC-BY-NC-ND 4.0 International license .

AMD, CVD and Stroke Page 1

\title{
Systemic and Genetic Risk Factors for Reticular Macular Disease and Soft Drusen in Age- Related Macular Degeneration
}

\section{Short title: Risk Factors for SDDs and Soft Drusen in AMD}

Robert J. Thomson, BS ${ }^{1}$

Joshua Chazaro, $\mathrm{BS}^{2}$

Oscar Otero-Marquez, $\mathrm{MD}^{3}$

Gerardo Ledesma-Gil, $\mathrm{MD}^{3,4,5}$

Yuehong Tong, $\mathrm{PhD}^{3,6}$

Arielle C. Coughlin, $\mathrm{BA}^{7}$

Zachary R. Teibel, $\mathrm{MD}^{8}$

Sharmina Alauddin, $\mathrm{MD}^{3}$

Katy Tai, BA ${ }^{3}$

Harriet Lloyd, BA ${ }^{3}$

Maria Scolaro, $\mathrm{MA}^{4}$

Arun Govindaiah, $\mathrm{MS}^{7}$

Alauddin Bhuiyan, $\mathrm{PhD}^{6}$

Mandip S. Dhamoon, $\mathrm{MD}^{8}$

Avnish Deobhakta, $\mathrm{MD}^{3}$

Jagat Narula, MD $^{9}$

Richard B. Rosen, $\mathrm{MD}^{3}$

Lawrence A. Yannuzzi, MD ${ }^{4}$

K. Bailey Freund, MD ${ }^{4,10}$

R. Theodore Smith, MD PhD ${ }^{3,6}$

${ }^{1}$ McGovern Medical School at The University of Texas Health Science Center, Houston, Texas.

${ }^{2}$ Loyola University Chicago Stritch School of Medicine, Maywood, Illinois.

${ }^{3}$ Department of Ophthalmology, New York Eye and Ear Infirmary of Mount Sinai, New York, New York, USA

${ }^{4}$ Vitreous Retina Macula Consultants of New York, New York, USA

${ }^{5}$ Retina Department, Institute of Ophthalmology Fundación Conde de Valenciana, Mexico City, Mexico

${ }^{6}$ Department of Ophthalmology, Icahn School of Medicine at Mount Sinai, New York, New York, USA

${ }^{7}$ Icahn School of Medicine at Mount Sinai, New York, New York, USA

${ }^{8}$ Hackensack University Medical Center, Hackensack, New Jersey, USA

${ }^{7}$ iHealthscreen Inc., New York, USA

${ }^{8}$ Department of Neurology, Icahn School of Medicine at Mount Sinai

${ }^{9}$ Department of Cardiology, Icahn School of Medicine at Mount Sinai

${ }^{10}$ Department of Ophthalmology, NYU Grossman School of Medicine. New York, New York, USA

Corresponding Author: 
medRxiv preprint doi: https://doi.org/10.1101/2021.09.27.21263712; this version posted September 29, 2021. The copyright holder for this preprint (which was not certified by peer review) is the author/funder, who has granted medRxiv a license to display the preprint in perpetuity.

It is made available under a CC-BY-NC-ND 4.0 International license .

AMD, CVD and Stroke Page 2

E-mail address: rts1md@gmail.com

Competing interests: Richard B. Rosen is a consultant to OptoVue, Boehringer-Ingelheim,

51 Astellas, Genentech-Roche, NanoRetina, OD-OS, Regeneron, Bayer, Diopsys and Teva. He has personal financial interests in Opticology, Guardion and CellView. K. Bailey Freund is a

53 consultant to Regeneron, Allergan, Zeiss, Bayer, Heidelberg Engineering and Novartis. He

54 receives research funding from Genentech/Roche. R Theodore Smith is a consultant to Ora

55 Technologies. The remaining authors have no relevant disclosures.

57 Funding: Regeneron Pharmaceuticals Investigator-Initiated Study, Research to Prevent

Blindness Challenge Grant, Macula Foundation (KBF), Bayer-Global Ophthalmology Awards Ear Infirmary Foundation (SA).

61

Keywords: age related macular degeneration; choroid; cardiovascular disease; drusen; genetics;

Summary Statement: Two phenotypes of age-related macular degeneration, soft drusen and reticular macular disease (the combination of subretinal drusenoid deposits and choriocapillaris insufficiency), are shown here to have distinct systemic vascular, serum, and genetic risks. These 
medRxiv preprint doi: https://doi.org/10.1101/2021.09.27.21263712; this version posted September 29, 2021. The copyright holder for this preprint (which was not certified by peer review) is the author/funder, who has granted medRxiv a license to display the preprint in perpetuity.

It is made available under a CC-BY-NC-ND 4.0 International license .

AMD, CVD and Stroke Page 3

\section{ABSTRACT}

Purpose: Soft drusen and subretinal drusenoid deposits (SDD) aka reticular macular disease (RMD) characterize two pathways to advanced age-related macular degeneration (AMD). We propose these pathways are distinct diseases, with distinct genetic risks, serum risks and associated systemic diseases.

Methods: 126 Subjects with AMD had: retinal imaging for RMD status, serum risks, genetic

81 testing, and histories of cardiovascular disease (CVD) and stroke.

82

Results: 62 subjects had RMD, 64 were nonRMD (drusen only), 51 had CVD or Stroke.

RMD correlated significantly with: ARMS2 risk allele ( $\mathrm{p}=0.019)$; lower mean serum HDL

$(61 \pm 18$ vs. $69 \pm 22 \mathrm{mg} / \mathrm{dl}, \mathrm{p}=0.038, \mathrm{t}$ test); CVD and troke (34/51 RMD, $\mathrm{p}=0.001)$.

NonRMD correlated/trended with: APOE2 $(\mathrm{p}=0.032)$ and CETP $(\mathrm{p}=0.072)$ risk alleles. 97

subjects total had some drusen, which correlated with $C F H$ risk $(\mathrm{p}=0.016)$. Multivariate $0.038)$.

90

91 Conclusion: The RMD and soft drusen AMD pathways have distinct systemic associations,

92 serum and genetic risks. RMD is associated with CVD and stroke, ARMS2 risk, and lower HDL;

93 drusen with CFH risk and two lipid risk genes. These pathways appear to be distinct diseases

94 leading to advanced AMD. 
medRxiv preprint doi: https://doi.org/10.1101/2021.09.27.21263712; this version posted September 29, 2021. The copyright holder for this preprint (which was not certified by peer review) is the author/funder, who has granted medRxiv a license to display the preprint in perpetuity.

It is made available under a CC-BY-NC-ND 4.0 International license .

AMD, CVD and Stroke Page 4

Multiple systemic, environmental and genetic risk factors have been identified for the complex disease of Age-related macular degeneration (AMD). However, assessment of the

98 disease impact of variables from so many sectors is difficult, and the pathogenic mechanisms

99 driving the disease itself are largely uncertain. We herein suggest that this problem be broken

100 into two largely independent disease pathways, which could be more easily analyzed separately.

101 These two pathways involve distinct lipid-laden deposits; one with lesions of soft drusen beneath

102 the retinal pigmented epithelium (RPE), and one with subretinal drusenoid deposits (SDD) above

103 the RPE ${ }^{1}$ (Figure 1). Both deposits can occur in the same eye (Figure 1B), and both can

104 progress to advanced $\mathrm{AMD},{ }^{2-4}$ of which SDD, aka reticular pseudodrusen (RPD), confers twice

105 the risk. $5,6,7$

106 An important further consideration is functional: the RPE is supplied by the choroidal

107 vasculature/choriocapillaris (CC). ${ }^{8} \mathrm{CC}$ insufficiency uniformly accompanies SDD on

108 indocyanine green angiography ${ }^{9}$ and non-invasive optical coherence tomography angiography

109 (OCTA) ${ }^{10}$ often accompanied by choroidal thinning and loss of choroidal volume. ${ }^{11}$ SDD are

110 topographically related to choroidal watershed zones, suggesting hypoxia in their pathogenesis. ${ }^{12}$

111 Hence CC insufficiency and SDDs have logically been combined together as the reticular

112 macular disease (RMD) phenotype of $\mathrm{AMD}^{9}$, and we will refer to this phenotype unambiguously

113 as SDD or RMD.

114 We propose these hypotheses to be explored initially herein and as a working basis for

115 productive future research in AMD.

116 Hypotheses: 1. The SDD and soft drusen pathways do not have the same systemic

117 associations, serum risks or genetic risks. 2. These pathways are in fact distinct diseases that only

118 merge in their common outcome in what is truly a single disease, advanced AMD (atrophic 
medRxiv preprint doi: https://doi.org/10.1101/2021.09.27.21263712; this version posted September 29, 2021. The copyright holder for this preprint (which was not certified by peer review) is the author/funder, who has granted medRxiv a license to display the preprint in perpetuity.

It is made available under a CC-BY-NC-ND 4.0 International license .

AMD, CVD and Stroke Page 5

119 and/or exudative). 3. Patient care could be personalized by consideration of the risk factors

120 pertinent to the disease pathway operative in a given individual. Research on the pathogenesis of

121 AMD could be well-served by identifying and differentiating those risk factors that apply

122 specifically to only one or the other pathway, enabling focused attention to specific risks and

123 single pathways, with corresponding simplification and higher chance of success.

$124 \quad$ Hypothesis 1 will be explored, amplified and supported in this paper.

125 Hypothesis 2. Evidence is presented here in the categories mentioned that SDD/RMD

126 and soft drusen are hallmarks of distinct diseases. Broad and persuasive support, to be

127 summarized, is already established.

128 Hypothesis 3 is theoretically self-evident, given Hypotheses 1 and 2 ,

129 Regarding Hypothesis 2: established multimodal imaging and anatomic distinctions

130 between the phenotypes include: scanning laser ophthalmoscopy (SLO), with autofluorescence

131 (AF) and near-infrared reflectance (NIR) imaging, which clearly identifies SDD as

132 hypoautofluorescent on AF and hyporeflectant on NIR, ${ }^{9}$ properties not shared by drusen;

133 histopathological identification of $\mathrm{SDD}^{13}$ in the subretinal space, with drusen in the sub-RPE

134 space, confirmed in vivo by spectral domain OCT (SD-OCT), ${ }^{14}$ with choroidal thinning

135 commonly found with SDD; and topographic localization of SDD with rod photoreceptors. ${ }^{15}$

136 SDD are associated epidemiologically with female gender and decreased longevity, ${ }^{5}$

137 systemically with coronary artery disease (CAD) in small case-control studies, ${ }^{2}{ }^{3}$ since

138 confirmed with OCTA documentation of CC insufficiency, ${ }^{16}$ and with cardiovascular cause of

139 death in donors. ${ }^{17} \mathrm{SDD}$ carry a worse prognosis for progression to advanced $\mathrm{AMD}^{6}$ and differing

140 associated subtypes of advanced AMD (both exudative, type 3 choroidal neovascuarization ${ }^{18}$ and 
medRxiv preprint doi: https://doi.org/10.1101/2021.09.27.21263712; this version posted September 29, 2021. The copyright holder for this preprint (which was not certified by peer review) is the author/funder, who has granted medRxiv a license to display the preprint in perpetuity.

It is made available under a CC-BY-NC-ND 4.0 International license .

AMD, CVD and Stroke Page 6

141 non-exudative, multilobular geographic atrophy ${ }^{7}$ ), biochemical composition, ${ }^{1}$ and functional

142 impact on rod-mediated dark adaption. ${ }^{19}$

143 Herein, we extended these disease distinctions with data on AMD risk alleles, serum risk

144 markers, and associations with vascular disease, as well as other demographic, ocular and

145 systemic features. We classified AMD patients into RMD (RMD present, either eye, +/- drusen)

146 with obligate underlying CC deficiency or non-RMD (large soft drusen only) by retinal imaging

147 for comparison

\section{Methods}

This was a multicenter prospective study conducted at two tertiary vitreoretinal referral

151 centers in New York City, USA: Vitreous Retina Macula Consultants of New York (LY, KBF),

152 and Department of Ophthalmology, New York Eye and Ear Infirmary of Mount Sinai School of

153 Medicine (MSSM) (RBR, RTS), from January 2019 to January 2021. The institutional review

154 board of MSSM approved the study, which adhered to the tenets of the Declaration of Helsinki.

155 ClinicalTrials.gov Identifier: NCT04087356.

\section{Inclusion and Exclusion Criteria.}

All patients older than 50 years, diagnosed with RMD/SDD and/or large soft drusen

159 lesions of AMD in either eye, who signed informed consent, and completed a study-related

160 questionnaire were included. Exclusion criteria were patients with other retinal degeneration and

161 vascular diseases, prior retinal surgery (except intravitreal injections), poor-quality imaging

162 and/or inconclusive medical or macular diagnoses. 
medRxiv preprint doi: https://doi.org/10.1101/2021.09.27.21263712; this version posted September 29, 2021. The copyright holder for this preprint (which was not certified by peer review) is the author/funder, who has granted medRxiv a license to display the preprint in perpetuity.

It is made available under a CC-BY-NC-ND 4.0 International license .

AMD, CVD and Stroke Page 7

164 Patient Evaluation.

Work-up included best-corrected visual acuity, slit lamp biomicroscopy, intraocular

166 pressure $(\mathrm{mmHg})$, blood samples for 9 AMD risk alleles and vascular disease risk factors, age,

167 gender, race/ethnicity, relevant family history, smoking, medication, and medical/ocular history

168 specifically covering stroke and these heart disease histories: myocardial infarction, coronary

169 artery bypass grafting (CABG), angina, arrhythmia, positive stress test, positive cardiac

170 catheterization, stent, valve disease and congestive heart failure (CHF) of any cause. Cases

171 confirmed against medical records were included in the cardiovascular (CVD) and stroke group.

172

173 Imaging.

174 Volume SD-OCT scans (27 lines, automated retinal tracking, 16 scans averaged per line),

175 and en face AF and NIR scans (both 30 degrees) centered on the fovea on the Heidelberg

176 Spectralis HRA + OCT (Heidelberg engineering, Heidelberg, DE).

177

178 Image Analysis.

179 SDD were identified on SD-OCT imaging as lesions of intermediate reflectivity above

180 the RPE followed a published protocol $^{2}$ for presence and most advanced stage independently and

181 then to consensus by two retina specialists (GLG, OOM). Any differences were resolved by a

182 senior grader (RTS). AF and NIR images were used to confirm the presence of SDD as fairly

183 uniform hypoautofluorescent or hyporeflective lesions in compact distributions with well-

184 defined borders. ${ }^{9}$ RMD status was determined by the presence of SDD alone, relying on

185 significant literature uniformly demonstrating CC insufficiency ${ }^{9,10} \quad{ }^{12,20}$ Soft drusen were

186 identified on SD-OCT imaging as lesions of intermediate reflectivity on Bruch's membrane 
medRxiv preprint doi: https://doi.org/10.1101/2021.09.27.21263712; this version posted September 29, 2021. The copyright holder for this preprint (which was not certified by peer review) is the author/funder, who has granted medRxiv a license to display the preprint in perpetuity.

It is made available under a CC-BY-NC-ND 4.0 International license .

AMD, CVD and Stroke Page 8

187 (BrM) elevating the RPE (Figure 1). Pigment epithelial detachments (PEDs) were included with 188 soft drusen. Other drusen phenotypes of lesser prevalence (calcified drusen, cuticular drusen)

189 were not included. A large soft drusen was required to be $>125$ microns in diameter. Choroidal 190 thickness (CTh) was measured on a central SD-OCT scan (Figure 1).

192 Serum CVD Risk Markers Analysis.

Blood samples for risk biomarkers of $\mathrm{CVD}^{21}$ (high-density lipoprotein cholesterol [HDL-

194 c], low-density lipoprotein cholesterol [LDL-c], triglycerides [TG], total cholesterol [TC] and

195 high sensitivity C-reactive protein [hsCRP]) were rapidly centrifuged at $1800 \mathrm{~g}$ for 10 minutes

196 and refrigerated. Lipid levels were measured (Quest Diagnostics, Teterboro, NJ) by

197 spectrophotometry, and plasma levels of hsCRP, by Immunoturbidimetric Assay (Orion

198 Diagnostica, Finland).

\section{Genetic Analysis.}

Blood samples for DNA were immediately stored at $-70^{\circ} \mathrm{C}$ until shipped on dry ice to

202 LGC Genomics (LGC, Biosearch Technologies, Hoddesdon, UK). Genomic DNA was extracted

203 from peripheral blood leukocytes according to established protocols. Genotyping was carried out

204 using KASP (Kompetitive Allele-Specific PCR, LGC Genomics) genotyping assays designed to

205 each target variant, within 1536 well PCR plates. Fluorescence was detected using the BMG

206 Pherastar (BMG LABTECH GmbH, Ortenberg, DE) and genotyping calls assigned based on 207 cluster plots within the LGC Genomics Kraken software.

208 The samples were assessed for single-nucleotide polymorphisms in 9 genes associated 
medRxiv preprint doi: https://doi.org/10.1101/2021.09.27.21263712; this version posted September 29, 2021. The copyright holder for this preprint (which was not certified by peer review) is the author/funder, who has granted medRxiv a license to display the preprint in perpetuity.

It is made available under a CC-BY-NC-ND 4.0 International license .

AMD, CVD and Stroke Page 9

210 identifies the H10 haplotype of $C 2 / B F)$, cholesteryl ester transfer protein $(C E T P)$, hepatic lipase

211 (LIPC), tissue inhibitor of metalloproteinase 3 (TIMP3), apolipoprotein genes (APOE2 and

212 APOE4). All are risk alleles except for the protective $C 2 / B F, L I P C$ and $A P O E 4$ alleles. ${ }^{22}$

213

214 Statistical Analysis.

215 Experts (AB, AG) used 'IBM SPSS Statistics version 27', 'Waikato Environment for

216 Knowledge Analysis (WEKA) Version 3.8.5', a data modeling tool, and Microsoft Excel 365.

217 Univariate statistics were chi square for categorical variables, two-tailed t-test for continuous

218 variables, with medians, ranges and/or interquartile ranges (IQRs) for non-normally distributed

219 data. Multivariate regression determined each variable's significance $(\mathrm{p}<0.05)$ after controlling

220 for all other covariates.

222 Results

223

224 Demographics and clinical characteristics.

62 subjects had SDD/RMD present (29 pure, without large soft drusen, and 33 mixed

226 cases) and 64, SDD absent (large soft drusen only). Five disagreements were resolved by

227 consensus without arbitration. For the RMD group, $67.7 \%$ were females and $32.3 \%$ were males.

228 The associations of demographic, ocular and clinical characteristics of patients with or without

229 RMD were not significantly different, except that acetylsalicylic acid (ASA) use was

230 significantly associated with RMD (53/62 RMD vs 30/64 nonRMD, $\mathrm{p}=0.007)$, and mean CTh

231 was less in left eyes with RMD than in nonRMD left eyes (Mean 146 \pm 58 vs. $177 \pm 59$ microns, 
medRxiv preprint doi: https://doi.org/10.1101/2021.09.27.21263712; this version posted September 29, 2021. The copyright holder for this preprint (which was not certified by peer review) is the author/funder, who has granted medRxiv a license to display the preprint in perpetuity.

It is made available under a CC-BY-NC-ND 4.0 International license .

AMD, CVD and Stroke Page 10

$232 \mathrm{p}=0.003$; median 161.5 , range $78-228$ microns vs. median 177.5 , range 90-286 microns) as

233 shown in Table 1.

234

235 Serum Risk Markers, CVD and Stroke.

236 Cholesterol panel and hsCRP mean values for RMD and non-RMD subjects were not

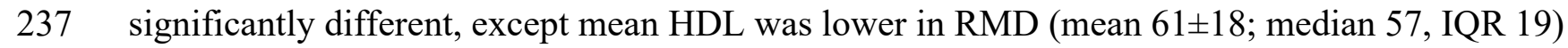

238 than non-RMD subjects (mean 69 $\pm 22, \mathrm{p}=0.038$; median 69, IQR 29) as depicted in Table 2.

239 Of the 126 subjects, 51 had CVD or stroke, 34/51 RMD ( $\mathrm{p}=0.001$, chi square).

240 Genetics.

The $A R M S 2$ risk allele frequency was significantly higher, $41.6 \%$, in the RMD group

242 than in the nonRMD group $(28.5 \%$, OR $1.79,95 \%$ CI $1.15-3.03, \mathrm{p}=0.03)$.

243 The $C F H$ risk allele frequencies were similar in the two groups $(56 \%$ and $53.2 \% ; \mathrm{p}=0.66)$.

Dividing the subjects analogously into Drusen (Drusen present, +/- RMD) or nonDrusen

245 (RMD only, no large soft drusen), the $C F H$ risk allele frequency was significantly higher, $61.4 \%$,

246 in the Drusen group than in the nonDrusen group $(36.8 \%$, OR $2.37,95 \%$ CI $1.16-4.76, \mathrm{p}=$

247 0.016). All other findings with this subdivision were NS.

$A P O E 2$ and $C E T P$ risk allele frequencies were higher in the nonRMD group than in the

250 RMD group (14.3\% vs 5.9\%, and 43.6\% vs 32.5\%, p= 0.03 and 0.07 , respectively). Allele

251 frequencies and significance of correlations with RMD or nonRMD of haplotype-tagging single-

252 nucleotide polymorphisms (SNPs) from the AMD-associated Loci are shown in Table 3. 
medRxiv preprint doi: https://doi.org/10.1101/2021.09.27.21263712; this version posted September 29, 2021. The copyright holder for this preprint (which was not certified by peer review) is the author/funder, who has granted medRxiv a license to display the preprint in perpetuity.

It is made available under a CC-BY-NC-ND 4.0 International license .

AMD, CVD and Stroke Page 11

Multivariate regression found CVD or stroke and $A R M S 2$ homozygous risk significant

256 for $\mathrm{RMD}$ risk ( $\mathrm{p}=0.008$ and $\mathrm{p}=0.038$, respectively), after controlling for all other parameters.

257 ASA use, a treatment for many vascular diseases, was not analyzed for multivariate RMD risk,

258 considering the evident strong association of vascular diseases with RMD/SDD.

260 Discussion.

261 The central hypothesis presented in this paper is that the SDD/RMD and soft drusen

262 pathways of AMD are actually two separate, but often co-existing, diseases that may result in a

263 single disease outcome, advanced AMD. The phenomenon of multiple, separate disease

264 pathways resulting in the same poor outcome and organ dysfunction is often the norm in

265 medicine rather than the exception, e.g., the many unique paths to heart failure. As mentioned

266 before, evidence for this pathophysiologic distinction has already accumulated from diverse

267 disciplines: anatomy, histology, imaging, retinal function, clinical outcomes, biochemistry, and

268 choroidal vascular physiology. Indeed, if all these facts had been known at the outset with the

269 discovery of the new lesion of SDD, the recognition of a completely distinct disease process

270 would have likely been clear and immediate.

We have shown herein that the SDD/RMD and soft drusen pathways also differ

272 significantly in their systemic associations, serum risks and genetic risks. In total, we suggest the

273 evidence is persuasive. As a corollary, this construct further supports revising the term AMD to

274 be reserved for the outcomes now known as advanced AMD, with age-related maculopathy

275 (ARMD) applied to any precursor state: RMD, drusen, other.

276 The $A R M S 2$ risk allele significantly correlated with reticular macular disease (RMD), the

277 combined phenotype of SDD and choriocapillaris insufficiency, compared to soft drusen; and the 
medRxiv preprint doi: https://doi.org/10.1101/2021.09.27.21263712; this version posted September 29, 2021. The copyright holder for this preprint (which was not certified by peer review) is the author/funder, who has granted medRxiv a license to display the preprint in perpetuity.

It is made available under a CC-BY-NC-ND 4.0 International license .

AMD, CVD and Stroke Page 12

278

279

280

281

282

283

284

285

286

287

288

289

290

291

292

293

294

295

296

297

298

299

300

CFH risk allele significantly correlated with soft drusen compared to RMD. These results replicate our previous discovery that $A R M S 2$ risk is significantly more correlated with RMD than nonRMD/pure drusen in AMD. ${ }^{23}$ The finding that $\mathrm{CFH}$ risk is significantly higher in all subjects with drusen than pure RMD, is new, but is consistent with our 2011 paper. This still leaves the possibility that both genes contribute to both pathways, but CFH weakly to SDD and ARMS2 weakly to soft drusen.

CVD and stroke are the leading causes of death in the developed world. AMD is the leading cause of blindness. ${ }^{4}$ Previous studies of AMD as a whole have failed to find consistent relations between these diseaes ${ }^{24-26}$ and in a large metanalysis, no associations. ${ }^{27}$ However, SDD and choroidal thinning specifically have been found to be associated with CAD in small studies. ${ }^{2,3}$ SDD also confer decreased longevity, ${ }^{5}$ with vascular death suspected. ${ }^{2,3}$ Histopathology of 1777 donor eyes ${ }^{17}$ found SDD, alone among AMD lesions, were associated with cardiovascular death. We have shown herein additional convincing evidence that CVD and stroke are strongly associated with the SDD/RMD type, not soft drusen.

The lipid dynamics of drusen with esterified cholesterol and SDD with non-esterified cholesterol ${ }^{1}$ are complex. Lipid in drusen and in the plaques of atherosclerotic disease (ASD) led to a long search for common mechanisms in these lesions. However, it is increasingly clear that drusen accumulation is associated with local blockage by abnormal BrM of normal absorption by the choroidal circulation of lipids secreted by the RPE. ${ }^{1}$ Further, as just reviewed, systemic vascular disease is associated with RMD, not drusen.

The risk marker of low serum HDL for ASD actually runs contrary for AMD, with higher HDL increasing risk. ${ }^{28}$ This apparent paradox may now be explained: prior studies considered only the drusen phenotype of AMD in color photos, and indeed, showed that high HDL is a risk 
medRxiv preprint doi: https://doi.org/10.1101/2021.09.27.21263712; this version posted September 29, 2021. The copyright holder for this preprint (which was not certified by peer review) is the author/funder, who has granted medRxiv a license to display the preprint in perpetuity.

It is made available under a CC-BY-NC-ND 4.0 International license .

AMD, CVD and Stroke Page 13

301 for drusen in AMD. ${ }^{28}$ Low HDL is a risk for CVD and stroke, which we now have found is a risk

302 for RMD, the other AMD pathway. HDL cuts both ways, depending on the pathway.

303 The many (29/62) cases of pure RMD (without drusen) further suggest that RMD is a

304 distinct retinal pathology. Damage from RMD then can lead, along with that of soft drusen, to

305 advanced AMD, with similar presentations. It should be noted, however, that the lesions of

306 geographic atrophy consequent to drusen or RMD still have distinguishing morphologic ${ }^{7}$ and

307 autofluorescence characteristics, ${ }^{29}$ consistent with different diseases.

308 The study has several weaknesses. The sample size is relatively small, so the results,

309 from a mostly Caucasian elderly population, require further examination in larger and diverse

310 cohorts e.g., in Asians, with the prevalent polypoidal choroidal vasculopathy form of AMD. ${ }^{30}$

311 RMD status was determined by the presence of SDD alone, relying for CC insufficiency on the

312 quite consistent literature ${ }^{9} 12,20$ without direct verification by OCTA; this can be added in future

313 studies. Important drusen phenotypes other than soft drusen, such as calcified drusen and

314 cuticular drusen, have their own identified risk factors, but were not included. Larger studies

315 with greater power will be doubtless be needed to determine the associations of such phenotypes

316 with lesser prevalence. Vascular histories were patient reported and were verified from medical

317 records only in positive cases with stated heart disease or stroke. More detailed data on cardiac

318 and carotid status should be included in future studies to help interpret these results.

319 Strengths of this prospective study at two tertiary retina referral centers include rigorous

320 patient selection and AMD phenotyping with high quality multimodal imaging for drusen and

321 RMD. It is significant that the associations from 3 new fields, systemic vascular disease, serum

322 risks and genetic risks, further differentiate the drusen and RMD pathways with new data that

323 extend the already broad platform of existing evidence. 
medRxiv preprint doi: https://doi.org/10.1101/2021.09.27.21263712; this version posted September 29, 2021. The copyright holder for this preprint (which was not certified by peer review) is the author/funder, who has granted medRxiv a license to display the preprint in perpetuity.

It is made available under a CC-BY-NC-ND 4.0 International license .

AMD, CVD and Stroke Page 14

\section{Conclusion}

The SDD/RMD and soft drusen pathways, now considered to be components of one disease, AMD, actually appear to be two separate, often co-existing diseases that only become

328 part of a single disease in their common outcome, advanced AMD.

330 shown here, many AMD patients demonstrate only one of these index lesions. Patient care could

331 be personalized by consideration of the risk factors pertinent to such individuals. Research on the 332 pathogenesis of AMD could also be well-served by identifying and differentiating those risk

333 factors that apply specifically to only one or the other pathway. These distinctions could enable

334 focused attention on specific risks and single pathways, with correspondingly higher chances of

335 success. The specific association between systemic vascular disease and RMD in particular

336 merits further study in the context of the choroidal vascular insufficiency that accompanies SDD

337 and defines RMD.

Acknowledgment: we gratefully acknowledge several helpful conversations with Christine

340 Curcio.

\section{REFERENCES}

343 1. Oak AS, Messinger JD, Curcio CA. Subretinal drusenoid deposits: further characterization by lipid histochemistry. Retina. 2014;34(4):825-826.

2. Cymerman RM, Skolnick AH, Cole WJ, Nabati C, Curcio CA, Smith RT. Coronary Artery Disease and Reticular Macular Disease, a Subphenotype of Early Age-Related Macular Degeneration. Curr Eye Res. 2016;41(11):1482-1488.

3. Ahmad M, Kaszubski PA, Cobbs L, Reynolds H, Smith RT. Choroidal thickness in patients with coronary artery disease. PLoS One. 2017;12(6):e0175691. 
350 4. Miller JW. Age-related macular degeneration revisited--piecing the puzzle: the LXIX Edward Jackson memorial lecture. Am J Ophthalmol. 2013;155(1):1-35 e13.

5. Klein R, Meuer SM, Knudtson MD, Iyengar SK, Klein BE. The epidemiology of retinal reticular drusen. Am J Ophthalmol. 2008;145(2):317-326.

6. Pumariega NM, Smith RT, Sohrab MA, LeTien V, Souied EH. A prospective study of reticular macular disease. Ophthalmology. 2011;118(8):1619-1625.

7. Xu L, Blonska AM, Pumariega NM, et al. Reticular macular disease is associated with multilobular geographic atrophy in age-related macular degeneration. Retina. 2013;33(9):1850-1862.

8. Hayreh SS. In vivo choroidal circulation and its watershed zones. Eye (Lond). 1990;4(Pt 2):273-289.

9. Smith RT, Sohrab MA, Busuioc M, Barile G. Reticular macular disease. Am J Ophthalmol. 2009;148(5):733-743.

10. Nesper PL, Soetikno BT, Fawzi AA. Choriocapillaris Nonperfusion is Associated With Poor Visual Acuity in Eyes With Reticular Pseudodrusen. Am J Ophthalmol. 2017;174:42-55.

11. Cheng H, Kaszubski PA, Hao H, et al. The Relationship Between Reticular Macular Disease and Choroidal Thickness. Current eye research. 2016;41(11):1492-1497.

12. Alten F, Clemens CR, Heiduschka P, Eter N. Localized reticular pseudodrusen and their topographic relation to choroidal watershed zones and changes in choroidal volumes. Invest Ophthalmol Vis Sci. 2013;54(5):3250-3257.

13. Rudolf M, Malek G, Messinger JD, Clark ME, Wang L, Curcio CA. Sub-retinal drusenoid deposits in human retina: organization and composition. Exp Eye Res. 2008;87(5):402-408.

14. Zweifel SA, Spaide RF, Curcio CA, Malek G, Imamura Y. Reticular pseudodrusen are subretinal drusenoid deposits. Ophthalmology. 2010;117(2):303-312.e301.

15. Curcio CA, Messinger JD, Sloan KR, McGwin G, Jr, Medeiros NE, Spaide RF. Subretinal drusenoid deposits in non-neovascular age-related macular degeneration: morphology, prevalence, topography, and biogenesis model. Retina. 2013;33(2):265-276.

16. Wang J, Jiang J, Zhang Y, Qian YW, Zhang JF, Wang ZL. Retinal and choroidal vascular changes in coronary heart disease: an optical coherence tomography angiography study. Biomed Opt Express. 2019;10(4):1532-1544.

17. Mano F, Sprehe N, Olsen TW. Association of Drusen Phenotype in Age-Related Macular Degeneration from Human Eye-Bank Eyes to Disease Stage and Cause of Death. Ophthalmol Retina. 2020.

18. Sawa M, Ueno C, Gomi F, Nishida K. Incidence and characteristics of neovascularization in fellow eyes of Japanese patients with unilateral retinal angiomatous proliferation. Retina. 2014;34(4):761-767.

19. Flamendorf J, Agron E, Wong WT, et al. Impairments in Dark Adaptation Are Associated with Age-Related Macular Degeneration Severity and Reticular Pseudodrusen. Ophthalmology. 2015;122(10):2053-2062.

20. Alten F, Heiduschka P, Clemens CR, Eter N. Exploring choriocapillaris under reticular pseudodrusen using OCT-Angiography. Graefes Arch Clin Exp Ophthalmol. 2016;254(11):2165-2173. 
medRxiv preprint doi: https://doi.org/10.1101/2021.09.27.21263712; this version posted September 29, 2021. The copyright holder for this preprint (which was not certified by peer review) is the author/funder, who has granted medRxiv a license to display the preprint in perpetuity.

It is made available under a CC-BY-NC-ND 4.0 International license .

AMD, CVD and Stroke Page 16

394

395

396

397

398

399

400

401

402

403

404

405

406

407

408

409

410

411

412

413

414

415

416

417

418

419

420

421

422

423

424

425

426

427

428

21. Yao H, Hou C, Liu W, Yi J, Su W, Hou Q. Associations of multiple serum biomarkers and the risk of cardiovascular disease in China. BMC Cardiovasc Disord. 2020;20(1):426.

22. Lambert NG, ElShelmani H, Singh MK, et al. Risk factors and biomarkers of age-related macular degeneration. Progress in retinal and eye research. 2016;54:64-102.

23. Smith RT, Merriam JE, Sohrab MA, et al. Complement factor $\mathrm{H} 402 \mathrm{H}$ variant and reticular macular disease. Archives of ophthalmology. 2011;129(8):1061-1066.

24. Alexander SL, Linde-Zwirble WT, Werther W, et al. Annual rates of arterial thromboembolic events in medicare neovascular age-related macular degeneration patients. Ophthalmology. 2007;114(12):2174-2178.

25. Duan Y, Mo J, Klein R, et al. Age-related macular degeneration is associated with incident myocardial infarction among elderly Americans. Ophthalmology. 2007;114(4):732-737.

26. Keilhauer CN, Fritsche LG, Guthoff R, Haubitz I, Weber BH. Age-related macular degeneration and coronary heart disease: evaluation of genetic and environmental associations. Eur J Med Genet. 2013;56(2):72-79.

27. Wang J, Xue Y, Thapa S, Wang L, Tang J, Ji K. Relation between Age-Related Macular Degeneration and Cardiovascular Events and Mortality: A Systematic Review and MetaAnalysis. Biomed Res Int. 2016;2016:8212063.

28. Colijn JM, den Hollander AI, Demirkan A, et al. Increased High-Density Lipoprotein Levels Associated with Age-Related Macular Degeneration: Evidence from the EYERISK and European Eye Epidemiology Consortia. Ophthalmology. 2019;126(3):393-406.

29. Monés J, Biarnés M. Geographic atrophy phenotype identification by cluster analysis. British Journal of Ophthalmology. 2017;102(3):388-392.

30. Wong CW, Wong TY, Cheung CM. Polypoidal Choroidal Vasculopathy in Asians. J Clin Med. 2015;4(5):782-821.

Figures and Legends:

Figure 1. Multimodal Imaging of Soft Drusen and Reticular Macular Disease (RMD) in Age-related Macular Degeneration (AMD).

Left. Near infrared reflectance (NIR) images. Right. Spectral domain optical coherence tomography (SD-OCT) images. The green lines on the NIR images denote the location of the corresponding B-scans on SD-OCT. 
medRxiv preprint doi: https://doi.org/10.1101/2021.09.27.21263712; this version posted September 29, 2021. The copyright holder for this preprint (which was not certified by peer review) is the author/funder, who has granted medRxiv a license to display the preprint in perpetuity.

It is made available under a CC-BY-NC-ND 4.0 International license .

AMD, CVD and Stroke Page 17

A. Soft drusen. NIR lesions of soft drusen have a hyperreflectant appearance. SD-OCT. Soft drusen (blue arrowheads) lie between the basal lamina of the retinal pigment epithelium (RPE) and the inner collagenous layer of Bruch's membrane (BrM), which is seen intermittently where the RPE is elevated. The choroidal thickness in this case is 287 microns.

B. Mixed drusen and RMD. NIR lesions of RMD are fairly homogeneous and moderately hypo-reflectant in a compact distribution with well-defined borders that is pathognomonic for RMD. SD-OCT. SDD Stage II lesions between the RPE and ellipsoid zone (EZ) are large enough to distort the EZ (yellow arrowheads). The choroidal thickness in this case is 284 microns.

C. Pure RMD. NIR shows pathognomonic hypo-reflectant lesions, more numerous superiorly as is usually the case. SD-OCT. A few stage I lesions not distorting the overlying EZ are seen between the stage II SDD. In this pure RMD (no soft drusen) the choroidal thickness is 213 microns, thinner than that in A and B, the soft drusen and mixed phenotypes. 


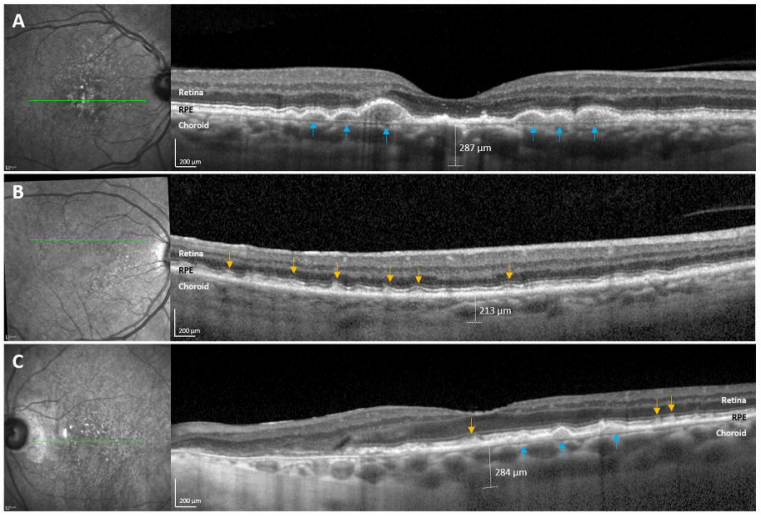

